\title{
Gluconeogenesis in the Kidney Cortex
}

\author{
EFFECTS OF D-MALATE AND AMINO-OXYACETATE
}

\author{
By R. ROGNSTAD AND J. KATZ \\ Medical Research Institute, Cedars-Sinai Medical Center, Los Angeles, Calif. 90029, U.S.A.
}

(Received 8 August 1969)

\begin{abstract}
1. Rat kidney-cortex slices incubated with D-malate alone formed very little glucose. D-Malate, however, augmented gluconeogenesis from L-lactate and inhibited gluconeogenesis from pyruvate and L-malate. 2. D-Malate had little effect on the rate of the tricarboxylic acid cycle with or without other substrates added. 3. D-Malate inhibited the activity of the L-malate dehydrogenase in a high-speed-supernatant fraction from kidney cortex. 4. It was concluded that D-malate inhibited either the operation of the cytoplasmic L-malate dehydrogenase or malate outflow from the mitochondria in the intact kidney-cortex cell. This supports the hypothesis of Lardy, Paetkau \& Walter (1965) and Krebs, Gascoyne \& Notton (1967) on the role of malate as carrier for carbon and reducing equivalents in gluconeogenesis. 5. Gluconeogenesis from L-lactate in kidney-cortex slices was strongly inhibited by a low concentration $(0.1 \mathrm{mM})$ of amino-oxyacetate, whereas glucose formation from pyruvate, malate, aspartate and several other compounds was only slightly affected. 6. High concentrations of L-aspartate largely reversed the inhibition of gluconeogenesis from L-lactate caused by aminooxyacetate. 7. Amino-oxyacetate inhibited strongly the glutamate-oxaloacetate transaminase in the $30000 \mathrm{~g}$ supernatant fraction of a kidney-cortex homogenate. The presence of $L$-aspartate decreased the inhibition of the transaminase by aminooxyacetate. 8. Detritiation of $\mathrm{L}_{-}\left[2-{ }^{3} \mathrm{H}\right]$ aspartate was inhibited by $90 \%$ during an incubation of kidney-cortex slices with L-lactate and amino-oxyacetate. 9. Low concentrations $(10 \mu \mathrm{M})$ of artificial electron acceptors such as Methylene Blue and phenazine methosulphate abolished most of the inhibition of gluconeogenesis from L-lactate by amino-oxyacetate. This is interpreted as an activation of net malate outflow from the mitochondria by-passing the inhibited transfer of oxaloacetate. 10. These findings support the concept that transamination to aspartate is involved in the transfer of oxaloacetate from mitochondria to cytosol required in gluconeogenesis from I-lactate.
\end{abstract}

It is generally believed that, in gluconeogenesis from L-lactate, oxaloacetate is produced in the mitochondria by the pyruvate carboxylase reaction and then must be transferred to the cytosol (Mehlman, Walter \& Lardy, 1967; Shrago \& Lardy, 1966). Oxaloacetate, however, apparently does not penetrate the mitochondrial membrane (Borst, 1963). Lardy, Paetkau \& Walter (1965) have produced evidence that a dual transaminase system may operate in this situation. In the mitochondria, oxaloacetate is transaminated to aspartate, which passes into the cytosol and is reconverted into oxaloacetate by the soluble glutamate-oxaloacetate transaminase. The system also requires free flow of glutamate and $\alpha$-oxoglutarate between the compartments.

L-Lactate and L-malate are on the same oxidation level as glucose, and dehydrogenases for these substrates are located in the cytosol. Thus no mitochondrially produced reducing equivalents are required when glucose is formed from either substrate. However, gluconeogenesis from pyruvate requires an additional source of reducing power. Lardy et al. (1965), Haynes (1965) and Krebs, Gascoyne \& Notton (1967) have proposed that mitochondrial NADH is used in this case: oxaloacetate in the mitochondria is reduced to malate, which leaves the mitochondria and then is reoxidized to oxaloacetate. Here malate is a carrier for both the carbon skeleton and the reducing equivalents used in glucose synthesis. The proposed pathways of gluconeogenesis from pyruvate and L-lactate thus differ in this region, with L-malate and L-aspartate being the respective carriers in the 


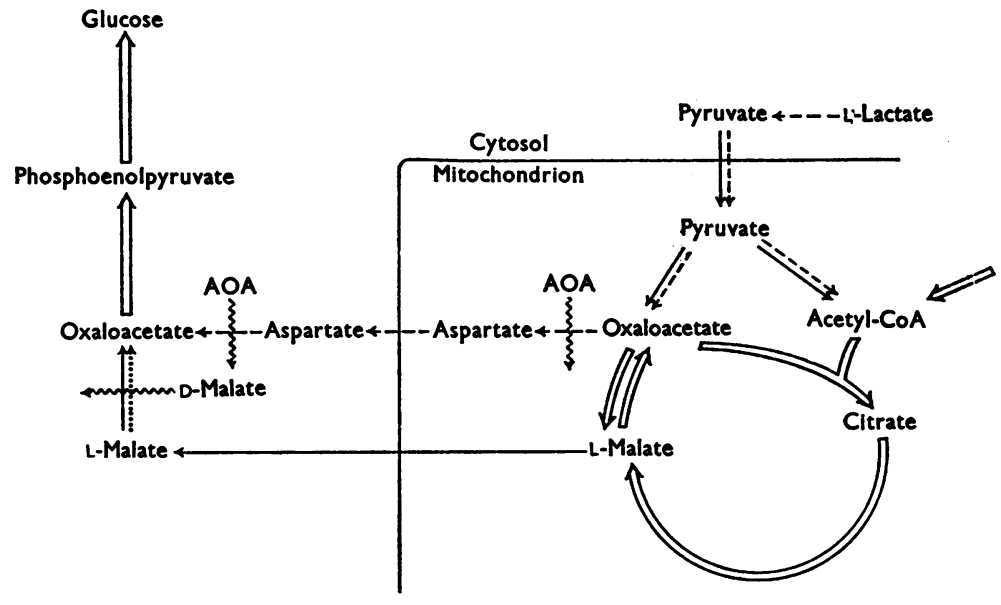

Scheme 1. Pathways of gluconeogenesis from pyruvate, L-lactate and L-malate. The pathways shown are those proposed by Lardy et al. (1965) and Krebs et al. (1967). The proposed gluconeogenic pathways from different substrates are shown by different arrows: solid arrows, pyruvate; dashed arrows, L-lactate; dotted arrows, L-malate. Common steps are shown by hollow arrows.

flow from mitochondria to cytosol. Gluconeogenesis from L-malate is strictly a cytoplasmic process.

In principle, if there are sufficiently specific inhibitors of the various steps at which the proposed gluconeogenic pathways from lactate, pyruvate and malate differ, it should be possible to test the hypotheses in the intact cell. Scheme 1 shows the pathways proposed by the workers above, the inhibitors used and the sites at which we believe the major inhibition to occur. We show in the present paper that D-malate inhibits gluconeogenesis from pyruvate but not from L-lactate. On the other hand, $\mathrm{AOA}^{*}$ diminishes glucose formation strongly from I-lactate but only slightly from pyruvate or I-malate. These results are consistent with Scheme 1.

\section{EXPERIMENTAL}

D-Malate was obtained from Calbiochem, Los Angeles, Calif., U.S.A. AOA was from Eastman Chemicals, Rochester, N.Y., U.S.A. L-[1-14 C]Lactate was from New England Nuclear Corp., Boston, Mass., U.S.A. L- $\left[2{ }^{3} \mathrm{H}\right]$ Aspartate was synthesized by incubating $500 \mu \mathrm{mol}$ of L-aspartate with 100 units of glutamate-oxaloacetate transaminase and $0.5 \mu \mathrm{mol}$ of pyridoxal phosphate in $1 \mathrm{ml}$ of tritiated water $(1 \mathrm{Ci} / \mathrm{ml})$ for $24 \mathrm{~h}$. The aspartate was purified by elution with $2 \mathrm{M}$-acetic acid from a column $(1 \mathrm{~cm} \times 30 \mathrm{~cm})$ of Dowex 1 (acetate form).

Male Wistar rats were starved for 18-48 h and killed by decapitation. Slices of kidney cortex were cut with a

\footnotetext{
* Abbreviation: AOA, amino-oxyacetate

$\left(\mathrm{H}_{2} \mathrm{~N} \cdot \mathrm{O} \cdot \mathrm{CH}_{2} \cdot \mathrm{CO}_{2} \mathrm{H}\right)$.
}

Mickle Chopper (Brinkman Instruments, Westbury, N.Y., U.S.A.). Portions ( $125 \mathrm{mg}$ ) of slices were incubated for $2 \mathrm{~h}$ at $37^{\circ} \mathrm{C}$ under $100 \% \mathrm{O}_{2}$ in $2 \mathrm{ml}$ of the buffer described by Krebs, Hems \& Gascoyne (1963), containing no bicarbonate. Incubations were carried out in $25 \mathrm{ml}$ Erlenmeyer flasks stoppered with rubber serum caps from which a plastic centre well Was suspended. At the end of the incubation, $0.5 \mathrm{ml}$ of $0.5 \mathrm{M}-\mathrm{H}_{2} \mathrm{SO}_{4}$ was injected into the medium and $0.3 \mathrm{ml}$ of $4 \mathrm{M}-\mathrm{NaOH}\left(\mathrm{CO}_{2}\right.$-free) was injected into the centre well. After collection of $\mathrm{CO}_{2}$, the flasks were opened and samples of the $\mathrm{NaOH}$ solution were taken for manometric $\mathrm{CO}_{2}$ determination. The aqueous phase was removed and the slices were washed, with the total volume of washings made to $10 \mathrm{ml}$. Samples were taken for glucose analysis (Slein, 1965).

To determine D-malate inhibition of the soluble L-malate dehydrogenase and AOA inhibition of glutamate-oxaloacetate transaminase, $4 \mathrm{~g}$ of kidney-cortex slices was homogenized in $36 \mathrm{ml}$ of $0.25 \mathrm{M}$-sucrose containing $10 \mathrm{~mm}$-tris-HCl buffer, $\mathrm{pH} 7.6$, and $5 \mathrm{~mm}$-EDTA. The homogenate was centrifuged at $1000 \mathrm{~g}$ for $10 \mathrm{~min}$ and then at $30000 \mathrm{~g}$ for $10 \mathrm{~min}$ and the final supernatant used.

The experiments in which $\mathrm{O}_{2}$ uptake was determined were carried out in Warburg flasks, with $0.3 \mathrm{ml}$ of $4 \mathrm{M}$ $\mathrm{NaOH}$ in the centre well. Slices (125 mg) in $2 \mathrm{ml}$ of buffer were in the main compartment, with substrates and inhibitors in $0.5 \mathrm{ml}$ of buffer in a side arm. The flasks were gassed with $\mathrm{O}_{2}$. Samples of the initial and final medium were taken for enzymic determination of pyruvate (Bücher, Czok, Lamprecht \& Latzko, 1965), L-lactate and L-malate (Hohorst, 1965).

\section{RESULTS}

Effects of D-malate on tricarboxylic acid-cycle metabolism. D-Malate is metabolized by kidneycortex slices, probably via the mitochondrial $D-\alpha$ - 
Table 1. Effect of D-malate on net carbon dioxide production, oxygen uptake and substrate utilization in kidney-cortex slices

The amount of substrate added was $10 \mu \mathrm{mol}$ in all experiments except Expt. 7, where $20 \mu \mathrm{mol}$ was added; $20 \mu \mathrm{mol}$ of acetate also was added in Expt. 7 only.

\begin{tabular}{|c|c|c|c|c|c|}
\hline \multirow{2}{*}{$\begin{array}{c}\text { Expt. } \\
\text { no. }\end{array}$} & \multirow[b]{2}{*}{ Substrate } & \multirow{2}{*}{$\begin{array}{l}\text { Concn. of } \\
\text { D-malate } \\
\text { (mM) }\end{array}$} & \multicolumn{2}{|c|}{$\begin{array}{c}\text { Gas exchange } \\
(\mu \mathrm{mol} / 2 \mathrm{~h} \text { per } 125 \mathrm{mg})\end{array}$} & \multirow{2}{*}{$\begin{array}{c}\text { Substrate } \\
\text { utilization } \\
(\%)\end{array}$} \\
\hline & & & $\mathrm{CO}_{2}$ formed & $\mathrm{O}_{2}$ used & \\
\hline \multirow[t]{8}{*}{6} & Endogenous & $\mathbf{0}$ & 17.3 & & \\
\hline & & 50 & 19.6 & & \\
\hline & Pyruvate & $\mathbf{0}$ & 23.0 & & \\
\hline & & 50 & 25.0 & & \\
\hline & L-Lactate & $\mathbf{0}$ & 25.9 & & \\
\hline & & 50 & 24.5 & & \\
\hline & L-Malate & $\mathbf{0}$ & 33.8 & & \\
\hline & & 50 & 23.7 & & \\
\hline \multirow[t]{12}{*}{7} & Endogenous & $\mathbf{0}$ & 38.8 & & \\
\hline & & 10 & 39.1 & & \\
\hline & & 20 & $\mathbf{3 8 . 0}$ & & \\
\hline & Pyruvate & 0 & 54.9 & & \\
\hline & & 10 & 49.4 & & \\
\hline & & 20 & 52.2 & & \\
\hline & L-Lactate & 0 & 42.9 & & \\
\hline & & 10 & 39.0 & & \\
\hline & & 20 & 41.0 & & \\
\hline & L-Malate & 0 & 48.7 & & \\
\hline & & 10 & 46.8 & & \\
\hline & & 20 & 41.1 & & \\
\hline \multirow[t]{8}{*}{8} & Endogenous & 0 & & 16.9 & - \\
\hline & & 50 & & 18.0 & - \\
\hline & Pyruvate & 0 & & 27.8 & 95 \\
\hline & & 50 & & 26.4 & 90 \\
\hline & L-Lactate & $\mathbf{0}$ & & 28.1 & 80 \\
\hline & & 50 & & 27.5 & 82 \\
\hline & L-Malate & 0 & & 29.4 & 90 \\
\hline & & 50 & & 27.2 & 48 \\
\hline \multirow[t]{8}{*}{9} & Endogenous & $\mathbf{0}$ & & 17.3 & - \\
\hline & & 50 & & 17.7 & - \\
\hline & Pyruvate & 0 & & 26.0 & 92 \\
\hline & & 50 & & 24.8 & 86 \\
\hline & L-Lactate & 0 & & 25.3 & 77 \\
\hline & & 50 & & 26.1 & 78 \\
\hline & L-Malate & 0 & & 30.1 & 92 \\
\hline & 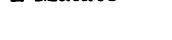 & 50 & & 28.5 & 54 \\
\hline
\end{tabular}

hydroxy acid dehydrogenase described by Tubbs \& Greville (1961). However, the rate of D-malate disappearance is only about one-fifth that of L-malate (R. Rognstad \& J. Katz, unpublished work). The effects of D-malate on net carbon dioxide production and oxygen uptake are shown in Table 1. In the absence of added substrate the material oxidized is probably endogenous lipid (Weidemann \& Krebs, 1969). Most of the carbon dioxide production is from tricarboxylic acid-cycle metabolism, and this was little affected by $50 \mathrm{~mm}-\mathrm{D}$ malate, the highest concentration used. Oxygen uptake was also unimpaired. 50 mM-D-Malate had little effect on net pyruvate utilization, indicating that entrance of pyruvate into the cell was not restricted. When I-malate was the substrate, carbon dioxide production was definitely depressed at the highest concentration $(50 \mathrm{mM})$ of D-malate, but this can be related to a rather strong inhibition of L-malate disappearance and consequent decrease in decarboxylation at C-4 of malate. This inhibition of malate utilization could be explained by an inhibition of the cytoplasmic L-malate dehydrogenase, but inhibition of entry of L-malate into the cell cannot be ruled out. The lack of any other marked effect of D-malate on oxygen uptake and carbon 
Table 2. Inhibition of kidney-cortex soluble L-malate dehydrogenase by $\mathrm{D}$-malate

The $30000 \mathrm{~g}$ supernatant from kidney-cortex homogenate was used as a source of the enzyme. The following assay system was used: $200 \mu \mathrm{mol}$ of tris-HCl buffer, $\mathrm{pH} 7.6,10 \mu \mathrm{mol}$ of acetyl phosphate, $1 \mu \mathrm{mol}$ of $\mathrm{CoA}$, $5 \mu \mathrm{mol}$ of $\mathrm{NAD}^{+}, 12$ units of transacetylase, 3 units of citrate synthase, $1 \mu \mathrm{mol}$ of L-malate and $10 \mu \mathrm{l}$ of kidney. cortex extract in a total volume of $3 \mathrm{ml}$. The reaction was followed in a Gilford recording spectrophotometer.

$\begin{array}{cc}\begin{array}{c}\text { Concn. of D-malate } \\ \text { (mM) }\end{array} & \begin{array}{c}\text { Initial rate } \\ \text { (\% of uninhibited rate) }\end{array} \\ 0 & 100 \\ 0.3 & 80 \\ 1.6 & 63 \\ 8.0 & 27\end{array}$

dioxide production suggests that none of the tricarboxylic acid-cycle enzymes was affected sufficiently to change the net flow.

Effect of D-malate on the cytoplasmic L-malate dehydrogenase from a homogenate of rat kidney cortex. The inhibition by D-malate of the oxidation of L-malate by the soluble L-malate dehydrogenase in a cell-free preparation is shown in Table 2. At a high D-malate/L-malate ratio the inhibition became pronounced. Chance \& Hagihara (1961) have reported that $D$-malate is a competitive inhibitor of L-malate dehydrogenase. Since malate dehydrogenase has been considered to be far from rate-limiting under normal conditions (Hohorst, Freutz \& Bücher, 1959; Krebs, 1967), a rather strong effect on this enzyme would be necessary to alter net flow in the cell. The results in Table 2 indicate that cytoplasmic I-malate dehydrogenase is a possible site of the effects of D-malate shown below.

Effect of D-malate on gluconeogenesis from Llactate, pyruvate and $\mathrm{x}$-malate. When added by itself, D-malate formed very little more glucose than that formed from endogenous sources in the kidney-cortex slice (Table 3). D-Malate at low concentrations increased gluconeogenesis from L-lactate and at higher concentrations had a variable effect. D-Malate inhibited gluconeogenesis from pyruvate at all concentrations tested. There was some inhibition by $D$-malate of glucose formation from I-malate, but the effect was less than that on gluconeogenesis from pyruvate.

Effect of AOA on glutamate-oxaloacetate transaminase. AOA has been shown to inhibit a number of transaminases, including glutamate-oxaloacetate transaminase (Roberts, Wein \& Simonsen, 1964 ; Braunstein, 1964; Hotta, 1968). The effect of AOA on the glutamate-oxaloacetate transaminase in a high-speed-supernatant fraction from a rat
Table 3. Effects of D-malate on gluconeogenesis from L-lactate, pyruvate and L-malate by kidney-cortex slices

Substrates were added at $10 \mu \mathrm{mol}$ in a total volume of $2 \mathrm{ml}$ in Expts. 1, 2, 3 and 5 and at $20 \mu \mathrm{mol}$ in Expt. 4; D-malate concentrations were varied as shown.

\begin{tabular}{|c|c|c|c|}
\hline $\begin{array}{c}\text { Expt. } \\
\text { no. }\end{array}$ & Substrate & $\begin{array}{c}\text { Concn. of } \\
\text { D-malate } \\
(\mathrm{mM})\end{array}$ & $\begin{array}{c}\text { Glucose formed } \\
(\mu \mathrm{mol} / 2 \mathrm{~h} \text { per } \\
125 \mathrm{mg} \text { wet wt })\end{array}$ \\
\hline 1 & Endogenous & $\begin{array}{l}\mathbf{0} \\
\mathbf{5}\end{array}$ & $\begin{array}{l}0.62 \\
0.80\end{array}$ \\
\hline 2 & $\begin{array}{l}\text { Endogenous } \\
\text { Pyruvate } \\
\text { L-Lactate }\end{array}$ & $\begin{array}{l}0 \\
0 \\
5 \\
0 \\
5\end{array}$ & $\begin{array}{l}0.43 \\
2.39 \\
1.82 \\
2.49 \\
2.67\end{array}$ \\
\hline 3 & $\begin{array}{l}\text { Endogenous } \\
\text { Pyruvate }\end{array}$ & $\begin{array}{r}0 \\
0 \\
5 \\
10\end{array}$ & $\begin{array}{l}0.48 \\
2.67 \\
2.18 \\
1.86\end{array}$ \\
\hline & L-Lactate & $\begin{array}{r}0 \\
5\end{array}$ & \\
\hline & L-Malate & $\begin{array}{r}10 \\
0 \\
5 \\
10\end{array}$ & $\begin{array}{l}\mathbf{3 . 6 7} \\
\mathbf{3 . 3 8} \\
\mathbf{3 . 3 5} \\
\mathbf{3 . 1 7}\end{array}$ \\
\hline 4 & Endogenous & $\begin{array}{r}0 \\
10 \\
20\end{array}$ & $\begin{array}{l}0.44 \\
0.45 \\
0.28\end{array}$ \\
\hline & Pyruvate & $\begin{array}{r}0 \\
10\end{array}$ & $\begin{array}{l}3.61 \\
2.64\end{array}$ \\
\hline & L-Lactate & $\begin{array}{r}20 \\
0\end{array}$ & $\begin{array}{l}1.71 \\
2.20\end{array}$ \\
\hline & & $\begin{array}{l}10 \\
20\end{array}$ & $\begin{array}{l}2.57 \\
2.15\end{array}$ \\
\hline & L-Malate & $\begin{array}{r}0 \\
10 \\
20\end{array}$ & $\begin{array}{l}2.71 \\
2.18 \\
1.78\end{array}$ \\
\hline 5 & $\begin{array}{l}\text { Endogenous } \\
\text { Pyruvate }\end{array}$ & $\begin{array}{l}\mathbf{0} \\
\mathbf{0}\end{array}$ & $\begin{array}{l}0.50 \\
3.47\end{array}$ \\
\hline & L-Lactate & $\begin{array}{r}50 \\
0\end{array}$ & $\begin{array}{l}1.90 \\
2.34\end{array}$ \\
\hline & L-Malate & $\begin{array}{r}50 \\
0 \\
50\end{array}$ & $\begin{array}{l}3.08 \\
2.84 \\
2.17\end{array}$ \\
\hline
\end{tabular}

kidney-cortex homogenate is shown in Table 4. At low concentrations of I-aspartate, AOA caused an immediate and strong inhibition of transaminase activity. At high concentrations of I-aspartate, inhibition of the initial rate by AOA was much less. However, the inhibition did increase with time.

Similar effects were found with a highly purified commercial glutamate-oxaloacetate transaminase from pig heart. With this purified enzyme, protection against AOA inhibition was also shown by high concentrations of L-glutamate. Hopper \& Segal (1962) have shown that AOA acts as a competitive 


\section{Table 4. Effect of $A O A$ on the soluble glutamate-oxaloacetate transaminase of the kidney cortex}

Each cuvette contained $300 \mu \mathrm{mol}$ of triethanolamine-HCl buffer, pH 7.4, $0.3 \mu \mathrm{mol}$ of NADH, L-aspartate as shown, $0.1 \mathrm{ml}$ of purified malate dehydrogenase $(5 \mathrm{mg} / \mathrm{ml}$; Boehringer) and $20 \mu \mathrm{l}$ of the high-speed supernatant fraction from the rat kidney cortex in a final volume of $1.0 \mathrm{ml}$. The reaction was started with $2 \mu \mathrm{mol}$ of $\alpha$-oxoglutarate. A control cuvette without aspartate run in each series gave a low rate of NADH oxidation. This was subtracted to give the rates shown.

$\begin{array}{cc}\begin{array}{c}\text { Concn. of aspartate } \\ \text { (mM) }\end{array} & \begin{array}{c}\text { Concn. of AOA } \\ \text { (mM) }\end{array} \\ 1.0 & 0 \\ 1.0 & 0.1 \\ 50.0 & 0 \\ 50.0 & 0.1\end{array}$

Initial rate
$\left(\Delta E_{340} / 2 \mathrm{~min}\right)$
0.159
0.011
0.468
0.270

Rate (\% of uninhibited rate) 100

7

100

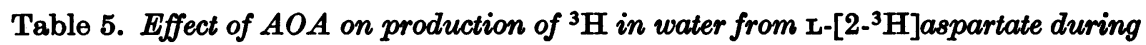
gluconeogenesis from $\mathrm{L}$-lactate

In these experiments $20 \mu \mathrm{mol}$ of L-lactate and $20 \mu \mathrm{mol}$ of acetate were incubated with $125 \mathrm{mg}$ of kidneycortex slices for $2 \mathrm{~h}$. The final volume was $2 \mathrm{ml}$. L- $\left[2-{ }^{3} \mathrm{H}\right]$ Aspartate $\left(4 \times 10^{6}\right.$ c.p.m.; $\left.1.1 \mu \mathrm{mol}\right)$ was added to separate replicate flasks at $0,30,60$ and $90 \mathrm{~min}$ and the amount of ${ }^{3} \mathrm{H}$ produced in water was determined by taking samples $15 \mathrm{~min}$ after addition of labelled substrate. During a $5 \mathrm{~min}$ incubation with $\mathrm{L}-\left[2{ }^{3} \mathrm{H}\right]-$ aspartate, about $60 \%$ of the ${ }^{3} \mathrm{H}$ was transferred to water in the absence of AOA.

\begin{tabular}{cccccc} 
Expt. & Concn. of AOA & \multicolumn{5}{c}{${ }^{3} \mathrm{H}$ in $\mathrm{H}_{2} \mathrm{O}(\%)$} \\
no. & $(\mathrm{mM})$ & $0-15 \mathrm{~min}$ & $30-45 \mathrm{~min}$ & $60-75 \mathrm{~min}$ & $90-105 \mathrm{~min}$ \\
15 & 0 & 98 & 99 & 100 & 100 \\
& 0.1 & 9 & 8 & 9 & 9 \\
16 & 0 & 93 & 98 & 99 & 99 \\
& 0.1 & 11 & 8 & 10 & 11
\end{tabular}

inhibitor of the amino acid substrates of glutamatepyruvate transaminase.

Table 5 provides evidence of the inhibition by AOA of glutamate-oxaloacetate transaminase in the intact cell. When L-aspartate was incubated in tritiated water with glutamate-oxaloacetate transaminase, ${ }^{3} \mathrm{H}$ was incorporated into aspartate at $\mathrm{C}-2$; this ${ }^{3} \mathrm{H}$ was again released to water on subsequent incubation with the enzyme in unlabelled water. When $\mathrm{L}-\left[2-{ }^{3} \mathrm{H}\right]$ aspartate was incubated with kidney-cortex slices, detritiation occurred (Table 5), with nearly all of the isotope appearing in water after $15 \mathrm{~min}$. The presence of $0.1 \mathrm{~mm}$-AOA resulted in only $10 \%$ detritiation. This is a minimal value for inhibition of the transaminase, since the $10 \%$ detritiation that did occur could possibly be the result of enzymes other than glutamate-oxaloacetate transaminase metabolizing L-aspartate.

Effect of AOA on gluconeogenesis. Gluconeogenesis from L-lactate (if one accepts a strictly mitochondrial site for pyruvate carboxylase) requires a transfer of oxaloacetate from the mitochondria to the cytosol. Lardy et al. (1965) have proposed a dual transaminase mechanism for this transfer. Thus a specific and potent inhibitor of glutamate-oxaloacetate transaminase might be expected to depress gluconeogenesis from lactate if this hypothesis is correct. The effect of AOA on gluconeogenesis in the rat kidney cortex is shown in Table 6. At an AOA concentration of $0.1 \mathrm{~mm}$, glucose formation from lactate was inhibited by 80-90\%. Glucose synthesis from all other substrates tested was inhibited by less than $15 \%$ at this concentration of AOA.

Reversal by L-aspartate of the AOA inhibition of gluconeogenesis from $\mathrm{L}$-lactate. At a concentration of $50 \mathrm{mM} \mathrm{L}$-aspartate alone formed little glucose in the kidney-cortex slice (Table 7). When added to 10 mM-L-lactate, this high concentration caused a moderate inhibition of gluconeogenesis. However, when added to L-lactate plus AOA, the strong inhibition of glucose synthesis caused by AOA was largely overcome. When $\mathrm{L}-\left[1-{ }^{14} \mathrm{C}\right]$ lactate was used as substrate, 50mM-L-aspartate abolished the inhibitory effect on the formation of $\left[{ }^{14} \mathrm{C}\right]$ glucose caused by AOA. The presence of aspartate decreased the yield of ${ }^{14} \mathrm{C}$ in glucose both in the absence and presence of AOA because of exchange by transaminase of labelled oxaloacetate with the large unlabelled aspartate pool. The results with L- $\left[1-{ }^{14} \mathrm{C}\right]$ lactate show that aspartate caused a true reversal of the inhibition of gluconeogenesis caused 
by AOA. An alternative explanation might have been that glucose was synthesized from oxaloacetate formed from aspartate in the cytosol and

Table 6. Effect of AOA on gluconeogenesis in the rat kidney cortex

Each flask contained $20 \mu \mathrm{mol}$ of the substrate together with $20 \mu \mathrm{mol}$ of acetate. The volume was $2 \mathrm{ml}$. Glucose formation from endogenous sources was $0.4-0.5 \mu \mathrm{mol} / 2 \mathrm{~h}$ per $125 \mathrm{mg}$ and has been subtracted to give the values in the table.

\begin{tabular}{|c|c|c|c|}
\hline $\begin{array}{c}\text { Expt. } \\
\text { no. }\end{array}$ & Substrate & $\begin{array}{l}\text { Concn. of } \\
\text { AOA } \\
\text { (mM) }\end{array}$ & $\begin{array}{l}\text { formation } \\
\text { ( } \mu \mathrm{mol} / 2 \mathrm{~h} \text { per } \\
125 \mathrm{mg})\end{array}$ \\
\hline \multirow[t]{7}{*}{10} & L-Lactate & $\begin{array}{l}0 \\
0\end{array}$ & $\begin{array}{l}2.72 \\
0.31\end{array}$ \\
\hline & Pyruvate & $\mathbf{0}$ & 3.05 \\
\hline & & 0.1 & 2.86 \\
\hline & L-Malate & 0 & 3.12 \\
\hline & & 0.1 & 2.98 \\
\hline & L-Aspartate & 0 & 1.10 \\
\hline & & 0.1 & 1.15 \\
\hline \multirow[t]{6}{*}{11} & L-Lactate & $\mathbf{0}$ & 2.72 \\
\hline & & 0.1 & 0.53 \\
\hline & L-Glutamate & $\mathbf{0}$ & 1.45 \\
\hline & & 0.1 & 1.25 \\
\hline & L-Glutamine & 0 & 1.11 \\
\hline & & 0.1 & 1.03 \\
\hline \multirow[t]{6}{*}{12} & L-Lactate & $\mathbf{0}$ & 2.84 \\
\hline & & 0.1 & 0.43 \\
\hline & L-Malate & 0 & 4.24 \\
\hline & & 0.1 & 3.93 \\
\hline & $\alpha$-Oxoglutarate & 0 & 4.55 \\
\hline & & 0.1 & 4.53 \\
\hline
\end{tabular}

NADH formed from L-lactate, in which case no transport of oxaloacetate from the mitochondria would have been required. However, the results with $\mathrm{L}-\left[1{ }^{14} \mathrm{C}\right]$ lactate indicate that aspartate removed the block in the flow of carbon from lactate to glucose. Presumably aspartate acted to prevent or decrease the inhibition by AOA of glutamateoxaloacetate transaminase.

Effect of artificial electron acceptors on the AOA inhibition of gluconeogenesis from lactate. The evidence presented above suggests that the inhibition of gluconeogenesis by AOA is caused by depression of oxaloacetate transfer as a result of inhibition of the glutamate-oxaloacetate transaminase either in the cytosol or in the mitochondria, or both. Since gluconeogenesis from pyruvate involves transfer of malate rather than oxaloacetate, no inhibition by AOA occurs. It seemed feasible that addition of a low concentration of an artificial electron acceptor such as Methylene Blue or phenazine methosulphate would alter the pathway of gluconeogenesis from lactate to be more similar to the pathway from pyruvate. These electron acceptors could react non-enzymically with the NADH generated from lactate in the cytosol, thus inducing malate outflow from the mitochondria to provide an additional source of cytoplasmic NADH. As shown in Table 8, low concentrations of the electron acceptors caused a moderate inhibition of gluconeogenesis from $\mathbf{L}$ lactate (and pyruvate). However, in this same concentration range these compounds brought gluconeogenesis from L-lactate plus AOA back to nearly the rate found in the absence of AOA.

Table 7. Reversal of AOA inhibition of gluconeogenesis by high concentrations of L-aspartate

Conditions were the same as in Table 6. In Expts. 14 and $15 \mathrm{~L}-\left[1 .{ }^{14} \mathrm{C}\right]$ lactate was used as substrate. Values in the last column are percentages of the added ${ }^{14} \mathrm{C}$ recovered in glucose.

\begin{tabular}{|c|c|c|c|c|c|}
\hline Expt. no. & $\begin{array}{c}\text { Concn. of } \\
\text { L-lactate (mM) }\end{array}$ & $\begin{array}{c}\text { Conen. of AOA } \\
(\mathrm{mM})\end{array}$ & $\begin{array}{c}\text { Concn. of } \\
\text { L-aspartate (mM) }\end{array}$ & $\begin{array}{c}\text { Glucose formed } \\
(\mu \mathrm{mol} / 2 \mathrm{~h} \text { per } 125 \mathrm{mg})\end{array}$ & $\begin{array}{c}{ }^{14} \mathrm{C} \text { in glucose } \\
(\%)\end{array}$ \\
\hline 13 & $\begin{array}{l}10 \\
10 \\
10 \\
10\end{array}$ & $\begin{array}{l}0 \\
0.1 \\
0 \\
0.1\end{array}$ & $\begin{array}{r}0 \\
0 \\
50 \\
50\end{array}$ & $\begin{array}{l}2.92 \\
0.52 \\
2.06 \\
1.78\end{array}$ & \\
\hline 14 & $\begin{array}{r}10 \\
10 \\
0 \\
0 \\
10 \\
10 \\
10 \\
10 \\
0 \\
0\end{array}$ & $\begin{array}{l}0 \\
0.1 \\
0 \\
0.1 \\
0 \\
0.1 \\
0 \\
0.1 \\
0 \\
0.1\end{array}$ & $\begin{array}{r}\mathbf{0} \\
0 \\
50 \\
50 \\
50 \\
50 \\
\mathbf{0} \\
0 \\
\mathbf{5 0} \\
\mathbf{5 0}\end{array}$ & $\begin{array}{l}2.88 \\
0.52 \\
0.20 \\
0.42 \\
2.06 \\
2.26 \\
2.69 \\
0.65 \\
0.42 \\
0.62\end{array}$ & $\begin{array}{c}9.3 \\
1.6 \\
- \\
- \\
3.4 \\
3.7 \\
10.7 \\
1.9 \\
- \\
-\end{array}$ \\
\hline 15 & $\begin{array}{l}10 \\
10\end{array}$ & $\begin{array}{l}0 \\
0.1\end{array}$ & $\begin{array}{l}50 \\
50\end{array}$ & $\begin{array}{l}2.27 \\
2.11\end{array}$ & $\begin{array}{l}3.9 \\
3.8\end{array}$ \\
\hline
\end{tabular}


Table 8. Effect of Methylene Blue or phenazine methosulphate on gluconeogenesis from $\mathrm{L}$-lactate in the absence and presence of $A O A$

Conditions were the same as in Table 6.

\begin{tabular}{|c|c|c|c|c|c|}
\hline $\begin{array}{l}\text { Expt. } \\
\text { no. }\end{array}$ & Substrate & $\begin{array}{c}\text { Concn. of AOA } \\
\text { (mM) }\end{array}$ & $\begin{array}{c}\text { Concn. of } \\
\text { Methylene Blue } \\
\text { (mM) }\end{array}$ & $\begin{array}{l}\text { Concn. of phenazine } \\
\text { methosulphate } \\
\text { (mM) }\end{array}$ & $\begin{array}{c}\text { Glucose formed } \\
(\mu \mathrm{mol} / 2 \mathrm{~h} \text { per } 125 \mathrm{mg})\end{array}$ \\
\hline \multirow[t]{6}{*}{1} & Lactate & - & - & - & 3.11 \\
\hline & & - & 0.01 & - & 2.63 \\
\hline & & - & 0.02 & - & 2.45 \\
\hline & & 0.1 & - & - & 0.54 \\
\hline & & 0.1 & 0.01 & - & 1.89 \\
\hline & & 0.1 & 0.02 & - & 2.19 \\
\hline \multirow[t]{15}{*}{2} & Lactate & - & - & - & 3.61 \\
\hline & & - & 0.005 & - & 3.19 \\
\hline & & - & 0.02 & - & 2.53 \\
\hline & & - & - & 0.005 & 2.63 \\
\hline & & - & - & 0.02 & 1.75 \\
\hline & Lactate & 0.1 & - & - & 0.45 \\
\hline & & 0.1 & 0.005 & - & 1.03 \\
\hline & & 0.1 & 0.02 & - & 1.87 \\
\hline & & 0.1 & - & 0.005 & 2.33 \\
\hline & & 0.1 & - & 0.02 & 2.21 \\
\hline & Pyruvate & - & - & - & 3.69 \\
\hline & & - & 0.005 & - & 3.17 \\
\hline & & - & 0.02 & - & 2.02 \\
\hline & & - & - & 0.005 & 2.78 \\
\hline & & - & - & 0.02 & 1.81 \\
\hline
\end{tabular}

\section{DISCUSSION}

Direction of net flow in the mitochondrial L-malate dehydrogenase reaction. We have found little effect of D-malate on tricarboxylic acid-cycle metabolism (Table 1). Our results possibly might not rule out an effect on the mitochondrial L-malate dehydrogenase, since according to the hypotheses of Lardy et al. (1965) and Krebs et al. (1967) this enzyme functions 'backwards' in gluconeogenesis from pyruvate. However, in our experiments on kidneycortex slices we do not confirm this speculation. Malate is formed by the forward reactions of the cycle and not by a net reduction of oxaloacetate with NADH. This can be shown as follows: analytical measurements in an experiment with pyruvate $(10 \mu \mathrm{mol})$ and kidney-cortex slices indicated that $8.5 \mu \mathrm{mol}$ of pyruvate disappeared, with $4 \mu \mathrm{mol}$ being converted into glucose and $2.5 \mu \mathrm{mol}$ into lactate, the remainder $(2 \mu \mathrm{mol})$ being presumably oxidized to acetyl-CoA and thence to carbon dioxide. Carbon dioxide formation was $28 \mu \mathrm{mol}$. A balance can be constructed from these results (Scheme 2). The results clearly show that under our conditions net flow in the mitochondrial malate dehydrogenase is in the forward direction, although a rapid reversible exchange reaction between oxaloacetate and malate may occur. Schmidt \&
Katz (1969) in this laboratory have found that in adipose tissue the mitochondrial malate dehydrogenase may function (net flow) in a reverse direction during active lipogenesis from pyruvate.

Mechanism of the inhibitory effect of D-malate. The only steps in the proposed (Lardy et al. 1965) pathway of gluconeogenesis from pyruvate that do not occur in the pathway from L-lactate are thus outflow of malate from the mitochondria and the cytoplasmic malate dehydrogenase reaction. DMalate inhibits gluconeogenesis from pyruvate and not (or only slightly) from L-lactate. We have shown (Table 2) that D-malate inhibition of malate dehydrogenase is possible. Haslam \& Griffiths (1968) have shown an effect of $D$-malate on penetration of L-malate into liver mitochondria and a similar effect on outflow could occur. Inhibition at either site is consistent with malate transfer being involved in gluconeogenesis from pyruvate. D-Malate depresses gluconeogenesis from and utilization of L-malate. However, these effects require high concentrations of $D$-malate, and a possible effect on L-malate uptake by the cell might also be considered.

Site of pyruvate carboxylase. The results with D-malate suggest that malate outflow is indeed involved in the utilization of mitochondrial reducing power required in glucose formation from pyruvate. 


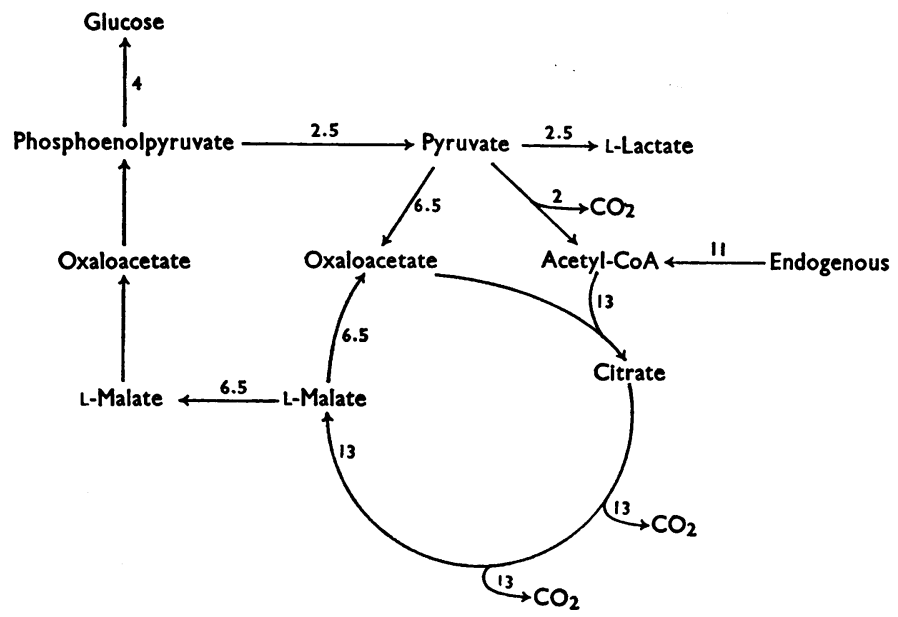

Scheme 2. Carbon flow in gluconeogenesis from pyruvate. Numbers represent $\mu \mathrm{mol} / 2 \mathrm{~h}$ per 125 mg wet wt.

This has some relevance to the controversy over the site of pyruvate carboxylase (see Scrutton \& Utter, 1968). Seubert \& Huth (1965) have provided evidence that in rat liver pyruvate carboxylase also occurs extensively in the cytosol. However, if malate is the carrier of reducing power, only a mitochondrial pyruvate carboxylase would suffice to maintain the dicarboxylic acid pool in the tricarboxylic acid cycle out of which malate flows. Bottger, Wieland, Brdiczka \& Pette (1969) have found nearly all of the pyruvate carboxylase activity in rat liver to be mitochondrial.

Mechanism of $A O A$ inhibition of gluconeogenesis. AOA has been shown to inhibit glutamato-oxaloacetate transaminase in a cell-free preparation (Table 4) and also to inhibit these enzymes in the intact cell (Table 5). Gluconeogenesis from Llactate in the kidney cortex is strongly inhibited by AOA, whereas glucose formation from pyruvate and L-malate is only slightly affected. These results provide strong confirmatory evidence for the role of the two transaminases in oxaloacetate transfer, as proposed by Lardy et al. (1965). High concentrations of aspartate tend to relieve both the inhibition of the transaminase in a cell-free system and the inhibition of gluconeogenesis. The reason for the complete lack of effect of AOA on glucose formation from L-aspartate is not clear (Table 6). One cause may be the protective effect of L-aspartate. However, much higher concentrations of L-aspartate (50 mM) were required to reverse effectively the AOA inhibition of gluconeogenesis from L-lactate. Another possibility is that other enzymes that metabolize L-aspartate may be present in kidney (e.g. an amino acid oxidase).

AOA has a strong inhibitory effect on gluconeo- genesis from lactate but not on that from pyruvate or that from lactate in the presence of Methylene Blue or phenazine methosulphate. The last results show that AOA does not inhibit lactate dehydrogenase in the kidney cortex. We have found (R. Rognstad \& J. Katz, unpublished work) no inhibition of a purified pig heart lactate dehydrogenase at an AOA concentration of $1 \mathrm{~mm}$.

Energy requirement for oxaloacetate transfer. Although these studies support the dual transaminase mechanism of oxaloacetate transfer, other considerations indicate that the mechanism may be more involved. Thus Krebs (1967) has estimated that in the liver of starved rats the oxaloacetate concentration in the mitochondria is nearly 100-fold lower than that in the cytosol. Transfer of oxaloacetate from the mitochondria to the cytosol thus should require energy, and the dual transaminase system by itself would not be adequate for the transfer. A possible solution to this dilemma is found in the hypothesis of de Haan \& Oestreicher (1968) that oxaloacetate is transferred between two compartments in the mitochondria by an energyrequiring process. One compartment includes malate dehydrogenase, and in this compartment the oxaloacetate concentration is low according to the calculations of Krebs (1967). The other compartment, to which oxaloacetate can be pumped and thus concentrated, includes glutamato-oxaloacetate transaminase. By a combination of the mechanism proposed by Lardy et al. (1965) and de Haan \& Oestreicher (1968), oxaloacetate could be transferred from the mitochondria to the cytosol.

Limit of the $\alpha$-glycerophosphate shuttle. Cytoplasmic and mitochondrial $\alpha$-glycerophosphate 
dehydrogenase have been reported in the kidney (Lee \& Lardy, 1965). Thus one might envisage a pathway of net malate outflow from the mitochondria even in gluconeogenesis from lactate, with the excess of reducing equivalents being returned to the mitochondria by an $\alpha$-glycerophosphate shuttle. The fact that AOA caused a pronounced inhibition in gluconeogenesis from lactate indicates that such an alternate pathway, if present at all, is severely restricted.

This work was supported by U.S. Public Health Service Grant no. AM-12604-01 and General Research Support Grant no. 5-S01 FR 05468-06.

\section{REFERENCES}

Borst, P. (1963). In Funktionelle und Morphologische Organisation der Zelle, p. 137. Ed. by Karlson, P. Berlin: Springer-Verlag.

Bottger, I., Wieland, O., Brdiczka, D. \& Pette, D. (1969). Eur. J. Biochem. 8, 113.

Braunstein, A. E. (1964). Vitams Horm. 22, 451.

Bücher, T., Czok, R., Lamprecht, W. \& Latzko, E. (1965). In Methods of Enzymatic Analysis, p. 253. Ed. by Bergmeyer, H. New York: Academic Press Inc.

Chance, B. \& Hagihara, B. (1961). Proc. 5th int. Congr. Biochem., Moscow, vol. 5, p. 3. New York: Pergamon Press Inc.

de Haan, E. J. \& Oestreicher, A. B. (1968). Abstr. FE BS 5th Meet., Prague, p. 52.

Haslam, J. M. \& Griffiths, D. E. (1968). Biochem. J. 109, 921.
Haynes, R. C. (1965). J. biol. Chem. 240, 4103.

Hohorst, H. J. (1965). In Methods of Enzymatic Analysis, p. 266. Ed. by Bergmeyer, H. New York: Academic Press Inc.

Hohorst, H. J., Freutz, F. H. \& Bücher, T. (1959). Biochem. Z. 332, 18.

Hopper, S. \& Segal, H. L. (1962). J. biol. Chem. 237, 3189.

Hotta, S. S. (1968). Archs Biochem. Biophys. 127, 132.

Krebs, H. A. (1967). In Advances in Enzyme Regulation, vol. 5, p. 409. Ed. by Weber, G. London: Pergamon Press Ltd.

Krebs, H. A., Gascoyne, T. \& Notton, B. M. (1967). Biochem. J. 102, 275.

Krebs, H. A., Hems, R. \& Gascoyne, T. (1963). Acta biol. med. ger. 11, 607.

Lardy, H. A., Paetkau, V. \& Walter, P. (1965). Proc. natn. Acad. Sci. U.S.A. 53, 1410.

Lee, Y. \& Lardy, H. A. (1965). J. biol. Chem. 240, 1427.

Mehlman, H. A., Walter, P. \& Lardy, H. A. (1967). $J$. biol. Chem. 242, 4594.

Roberts, E., Wein, J. \& Simonsen, D. G. (1964). Vitams Horm. 22, 503.

Schmidt, K. \& Katz, J. (1969). J. biol. Chem. 244, 2125. Scrutton, M. C. \& Utter, M. F. (1968). A. Rev. Biochem. 37, 249.

Seubert, W. \& Huth, W. (1965). Biochem. Z. 343, 176. Shrago, E. \& Lardy, H. A. (1966). J. biol. Chem. 241, 663.

Slein, M. W. (1965). In Methods of Enzymatic Analysis, p. 117. Ed. by Bergmeyer, H. New York: Academic Press Inc.

Tubbs, P. K. \& Greville, G. D. (1961). Biochem. J. 81, 104.

Weidemann, M. J. \& Krebs, H. A. (1969). Biochem. J. $112,149$. 